Emma Vázquez-Espinosa

Claudio Laganà ${ }^{2}$

Fernando Vazquez $z^{3,4,5,6}$

\title{
John Donne, Spanish Doctors and the epidemic typhus: fleas or lice?
}

'Servicio de Neumología, Hospital Universitario La Princesa, Madrid, España

${ }^{2}$ Servicio de Radiodiagnóstico, Hospital Universitario La Princesa, Madrid, España

${ }^{3}$ Servicio de Microbiología. Hospital Universitario Central de Asturias, Oviedo, España.

${ }^{4}$ Departamento de Biología Funcional, Área de Microbiología, Facultad de Medicina. Universidad de Oviedo, Oviedo, España.

${ }^{5}$ Instituto Oftalmológico Fernández-Vega, Fundación de Investigación Oftalmológica, Universidad de Oviedo, Oviedo, España.

${ }^{6}$ Grupo de Microbiología Translacional, Instituto de Investigación Sanitaria del Principado de Asturias (ISPA), Oviedo, Spain.

Article history

Received: 14 December 2019; Accepted: 16 January 2020; Published: 7 February 2020

\begin{abstract}
We describe the infections that appeared in the life and work of John Donne (1572-1631), the English metaphysical poet, mainly the exanthematic typhus that suffered and gave arise to his work Devotions upon emergent occasions, and several steps in my sickness. We discuss the vector of transmission of this disease, in comparison of other infections in that period, that Donne's scholars have related to the flea without mentioning the body louse, the true vector of the exanthematic typhus. Likewise, we mention the exanthematic typhus's symptoms in his Devotions in comparison with the Luis de Toro's or Alfonso López de Corella's works, Spanish doctors in those times and the first doctors in write books about the disease, and the singular treatment of pigeon carcasses on the soles of the feet in English Doctors but not in Spanish Doctors.
\end{abstract}

Key-words: Exanthematic typhus, lice, Devotions, John Donne, Spanish doctors

\section{John Donne, médicos españoles y el tifus epidémico: ¿pulgas o piojos?}

\section{RESUMEN}

Se describen las infecciones que aparecieron en la vida y la obra de John Donne (1572-1631), el poeta metafísico inglés, principalmente el tifus epidémico que padeció y que dio lugar a su obra "Devotions upon emergent ocassions, and several steps in my sickness". Discutimos el vector transmisor

Correspondence:

Fernando Vázquez Valdés

Servicio de Microbiologia. Hospital Universitario Central de Asturias, Avda. de Roma s/n 33011 Oviedo, España.

Tfno.: 630243480

E-mail: opsklins@gmail.com de la enfermedad, en comparación de otras infecciones en ese periodo, que los estudiosos de Donne han relacionado a las pulgas y sin mencionar el piojo del cuerpo que es el verdadero vector del tifus epidémico. Además, mencionamos los síntomas de la enfermedad en su obra "Devotions" en comparación con los trabajos de Luis de Toro o Alfonso López Corella, médicos españoles de su tiempo y los primeros en escribir los tratados sobre la enfermedad, y el tratamiento singular de las carcasas de palomas en las palmas y plantas de los pies en los médicos ingleses pero no presente en los médicos españoles.

\section{INTRODUCTION}

The first three treaties on epidemic or exanthematic typhus were from the Spanish doctors Alfonso López de Corella (c. 1519-1584), Luis Mercado (c. 1520-1606) and Luis de Toro (c. 1532-1591), printing in Zaragoza, Valladolid and Burgos, respectively. As Arrizabalaga remarks: "behind the word and the label of epidemic typhus there are several entities with which they were confused" [1], for example the distinction between typhoid fever and exanthematic typhus occurred already in modern times.

In this review, we describe the infections that appear in the life and work of Donne, fundamentally the exanthematic typhus that suffered and gave arise to his work Devotions upon emergent occasions, and several steps in my sickness and we discuss the vector of transmission of this disease that Donne's scholars have related to the flea without mentioning the body louse and as a source of contagion through the dresses of his time. Likewise, we mention the exanthematic typhus's symptoms in his Devotions in comparison with the Luis de Toro's or Alfonso López de Corella's works and the singular treatment of pigeon carcasses on the soles of the feet in English Doctors but not in Spanish Doctors.

John Donne (1572-1631). John Donne has been defined as a metaphysical poet, denomination coined by his enemies [2], 
and is known above all for his quotes as "No man is an island, entire of itself; every man is a piece of the Continent, a part of the main... "and "Any therefore never send to know for whom the bell tolls; it tolls for thee". Contemporary of Shakespeare, who is believed to be also crypto-Catholic, and the Quixote of Cervantes is a writer who was little understandable, close to the baroque poetry of Luis de Góngora, and therefore he was postponed for a long time. Also, he changed from Catholicism to Anglicanism, at a time that being of this religion in England was a very great danger of death, and of writing erotic and love poems to become a cleric and dean of St Paul's Cathedral in London. He has been described as a flatterer and adventurer who participated in his youth in the attack of the Earl of Essex against Cadiz (Spain) in 1596. Also, in some of his works such as the "Elegy to his mistress going to bed" censored and, that was not published until 1669, a pornographic Donne and full of eroticism is displayed [2].

In the poem "Whispers of Immortality", TS Eliot places Donne in the same category as John Webster (1580-1633), those writers with a depressive disposition. The melancholy was a typical vision of the 17th century as in the book of Robert Burton (1577-1640), Anatomy of the Melancholy (1621), and Webster in the Elizabethan Age [3]. There is an obsession in Donne for mortality in all his works, the result of his time: at that time mortality, especially in newborns, was very high (five out of his children died), a certain depression of his personality and his concerns by lack of money, the existence of epidemics such as plague, typhus, smallpox and cholera, the executions and funerals that were public. The culture of melancholy was prevalent in that period [3].

\section{INFECTIONS AND JOHN DONNE}

The infections prevalent in Donne's time were typhus, dysentery and smallpox [4], but plague and other infections were present in Donne's life in addition to the epidemic typhus:

a) Pharyngotonsillitis. Throughout his life, Donne had repeated attacks of intermittent mild fever that have been labeled as probable episodes of pharyngotonsillitis [3].

b) Plague. Donne attributes it to vapors and humidities of the earth and the flea says that "although it does not kill, it produces all the damage it can". One of Donne's most popular erotic poems is The flea, due to the frequency of fleas in the Renaissance and the appearance of the plague. In this poem, the flea, it is a sexual metaphor. The argument is the refusal of the woman to have sex and how to convince her to make love, if a flea takes blood from the woman and after the man, both bloods are mixed in the flea, why not do it in the same way in the sexual act and its consummation as the image of the flea and the blood?. Also, in the original English, the word maidenhead in the poem means hymen so the poem implies that the woman is a virgin. It is believed that he wrote it when he was young and was studying law and that he did it to impress his male classmates. The poem was not published until two years later, in 1633, of Donne's death [5]. c) Greatpox. In his poem The aparition says [6]:

And then poor aspen wretch, neglected thou

Bath'd in a cold quicksilver sweat wilt lie

A verier ghost than I ...

(II. 11-13)

(pobre álamo tembloroso,

yacerás bañada en un frio sudor de mercurio,

más fantasmal que yo )

Mercury (quicksilver) was a treatment for greatpox, or misnamed currently syphilis, here of a woman called "false vestal" indicating that she carries a sexually transmitted infection, and ends the poem sinisterly [5]:

since my love is spent,

I'had rather thou should'st painfully repent,

Than by my threat'nings rest still innocent.

(15-17)

(puesto que mi amor ya no existe,

me gustaría que te arrepientas con dolor,

más que a que por miedo seas inocente).

d) Exanthematic typhus. Donne already had had an encounter with the disease 30 years earlier, in 1593, the typhus had killed his brother Henry in prison after having housed a Catholic priest. He refers to this event and exposes it in Expostulations XVIII. In the biography that accompanies the edition of One Hundred Poems in Spanish (100 poemas en español, Editorial Pretextos), it is said that he died of plague in jail [7], but at that time typhus was more typical in prisons.

\section{EXANTHEMATIC TYPHUS AND DEVOTIONS}

a) Chronology. On November 22, 1623, Donne presides over a trial and is his last appearance before becoming ill on November 23-24. Donne suffers from the first symptoms of an infection that most scholars think it was an exanthematic typhus, some scholars think it could be a flu, tuberculosis or recurrent fever and that in any case the nature of their disease would be unproven $[8 \mathrm{a}, 8 b]$. The most likely diagnosis by the symptoms, in any case, was typhus in an epidemic that devastated London that year and that killed around 8,000 people and that closed the Parliament from September 4 to February 15, 1624 [9]. At that time Donne was dean of St. Paul's Cathedral, he had already written most of his poetry and sermons.

The disease prostrates him about 20 days and writes one of his most famous books: Devotions upon emergent occasions, and several steps in my sickness, [10] which is 
divided into 23 parts or chapters that are each of them subdivided into the Meditations, Reconventions and Prayer sections, the three emblematic parts of the Holy Spirit, but also the internal structure in 3 parts of each chapter should be read as the morning, late entries and night of a medical history: Meditations represent the symptoms collected from each day in a rational and scientific way, at noon (Reconventions) the dissatisfaction appears and with the increase of the fever the protests appear with biblical references, so the section Prayer is the shorter of the three [11]. It is partly a personal diary, meditation and prayer and is one of the most accurate, and in the first person, examples of the literary description of a disease [12]. It is a metaphorical construction and the analogy of the disease of the body and the disease of the soul [13] with precise observations of his illness, the treatments applied and his recovery. In the 14 days of the disease progress, descriptions of the symptoms that match an exanthematic typhus are made. In addition, his recovery was slow, about 3 months since he does not give another sermon until March 28 on 1624 in St. Paul's Cathedral [13].

b) Doctors who treated John Donne. Since the reign of Henry VIII, there was an act that said that medicine could not be practiced in London unless the doctor was reviewed and endorsed by the Bishop or Dean of St. Paul's Cathedral, so Donne knew his doctors [14]. Donne's known doctors, and who had a relationship with William Harvey, were Simeon Fox and William Clement [3]. Those who assisted him in his illness were first his friend Simeon Foxes and due to the seriousness of the picture the doctor of King James I, Theodore Turquet de Mayerne. Mayerne introduced the calamine lotion, lotio nigra (lotion used for syphilitic and scrofulous ulcers) into the pharmacopoeia of his time, and an early form of laudanum. He wrote after treating Donne, a treatise in Latin Ad febram purpurean about typhus (the typhus was called purple fever) [15]. This supports the fact that Donne's disease was an exanthematic typhus since at that time the typhus was well known to doctors and previously Fracastoro in his book De Contagione in 1545 classifies pestilent fevers and gives the first description of typhus.

c) Denomination of the disease. The body louse is known to transmit the trench fever by Bartonella quintana, the recurrent fever by Bartonella recurrentis, the exanthematic typhus by Rickettsia prowazekii and the plague by Yersinia pestis. Exanthematic typhus (the etymology means: smoke, fog, senselessness or stupor caused by fever), has been closely linked to epidemics in wars since time immemorial. Typhus, as a clinical concept, appears in the work of Persian doctors, 'Homay-e mohregheh' (typhic fever) and the clinic is described in the book al-Hāwi, Oānun fi'l -tebb (Canon of medicine) by Abu Bakr Mohammad Ibn Zakariyā Rāzi and in the Dakira-ye kvārazmšāhi (Treasure of the kvārazmšāh) by Esmāil Jorjāni. The latter one, he describes the symptoms and rash as well as its mortality and recommends washing the patient's body with cold water, calling to the typhus mohregheh and to typhoid motabhbegheh fever. Several fevers including typhus are also described in the oldest treatise on Persian medicine written about 983: Hedāyat al-mota'allemin fi'l-tebb by Akawayni Bokāri [16].

In the 16th century in Spain, the word typhus had several denominations: "punticular" or "lenticular" fever (derived from lentil due to the size of the spots on the skin), "pulicularis" (derived from fleas), "aphid", "tabardillo", "tabardete", "pintas" (denominations by the common people) or "tabardillo pintado (painted)" described by the doctor Luis del Toro in 1557 [17]. The Spanish doctors who studied the typhus at this time were: Alfonso López de Corella and Luis de Luis Toro, both in 1574, and Luis Mercado, in 1586. Alfonso López de Corella (15131584), published an important and original text dedicated to exanthematic typhus, called by the Spanish Renaissance doctors "morbus lenticularis", "tabardillo", or "pintas", for dermatological lesions "similar to flea bites". This text appeared under the title of: De morbo pustulato sive lenticulari, quem nostrates Tabardillo appellant liber unus, atque de Galeni Placitis liber alter, quo omnibus fere medicis qui praedictum auctorem hucusque impugnarunt respontur ...[18].

The word "tabardillo" (1570) derives from the eruption of spots that covers the entire body like a tabard [19] and De Covarrubias in his Treasury of the Castilian or Spanish language (1611) [20] says that it is named after the Latin "Tabes" that it means rot, because the blood rots or corrupts [19]. An excellent review of the term "tabardillo" is collected by Jon Arrizabalaga and it is out of the scope of this review [1].

It is however, Luis de Toro who makes a reliable description of the symptoms considering himself the first and most important doctor of the "tabardillo" [17]. De Toro describes the pustules as "almost never bloom from the beginning (of fever), but on the fourth, fifth, sixth, seventh day, and even later", also "the spots that are seen never accuse any detectable tumor to the touch, but they are as if someone stained the meat with ink dots ". As a measure to avoid it already describes that "you must run away from the dresses and shirts of the sick".

Gregorio Marañón (1887-1960) made a fairly precise description of the clinical picture: he observes that the picture begins with 3 days of progressively ascending fever that ends with a sudden crisis, after 2 to 4 weeks of feverish picture. There is an intense headache and conjunctival injection. The rash appears from the third to the sixth day with a rash (skin rash), first congestive and then petechial (live red spot, similar to the flea bite, which does not disappear at the pressure of the finger), and even hemorrhagic. Marañon says that there is the tremor in the hands and the frequent "typhoid state" of the patients. Complications include myocarditis, neurological manifestations, and involvement of the parotid glands. The duration of the disease is 14 to 16 days. Towards the 10th day is the crucial moment of the disease, either the patient worsens with presentation of coma and consecutive death, or begins to improve in a definitive way [21].

The typhoid state also was known as the "new fever", "Irish fever" or "flea bite fever", the name of exanthematic typhus was given by the French doctor Boissier De Sauvages in 1760. The rash of typhus was differentiated of the typhoid 
by Huxham in 1739 and subsequently Gerhard, histologically, based on the absence of ulcers in Peyer's corpuscles during the 1836 Philadelphia epidemic.

\section{SOURCE AND TRANSMISSION OF DONNE'S TYPHUS: FLEAS OR LICE?}

The exanthematic typhus is produced by the bacterium Rickettsia prowazekii and transmitted by the body louse (Pediculus humanus var. corporis), in exceptional cases there have been cases transmitted by the head louse (Pediculus humanus var. capitis). In his book Devotions, Donne talks about the flea as the cause of his illness. Although typhus transmission by fleas is possible by aerosols, this pathway is very rare and exceptional since the body louse is the main vector involved and it is suspected, although is controversial, that in some cases also ticks. At that time, the fleas were causing the bubonic plague produced by Yersinia pestis and was associated with the transmission of typhus, curiously today it is known that the plague can also be transmitted by the body louse [22]. Spanish Renaissance doctors, as we had indicated above, comment that dermatological lesions are "similar to flea bites", hence the confusion with the typhus vector. In a molecular study, three scenarios of plague transmission in Europe have been established between the 14th and 19th centuries: the first would be the classical dissemination of rodents and fleas, the second by humans who spread pneumonic plague through coughs and the third that has been seen to be the most likely is that lice and fleas spread the plague and did not depend so much on the increase in rats [23]. In the time of Donne, fleas could easily coexist with the patients (in an average of 6 fleas) with the body louse that remain infectious for a period of 3 days [23].

On the contrary, the possibility that fleas transmit exanthematic typhus is unlikely, although fleas can transmit other Rickettsias (murine typhus for example), and is recognized as a transmission mechanism only to the body louse when it is epidemic and in cases of recrudescence (BrillZinser disease) is transmitted by humans. Only in the eastern United States has been seen transmission, by lice and fleas, between flying squirrels (Glaucomys volans) although this mechanism is not clear [22].

None of the scholars on Donne, and included in the bibliography of this work, although they mention the possible infections that could be the cause of Donne's clinical picture described in his Devotions, refers to the possibility of transmission by the body louse and is assumed that the transmission is by fleas, the prevailing idea is that period, something that is, as we indicate, quite unlikely. In one study, the author indicates that typhus was often confused with the plague and that "in fact, there is a strong analogy between the two diseases, both derived from a similar source, mainly rats and infestation with fleas..." [11]. The presence of two coincident and overlapping epidemics occurred in Andalucia between 1569 and 1570: in Seville and Puerto de Santa María, people died of "Iandres" or plague and in areas such as Bazan of "modorra" or typhus [24]. In the same way, both overlapping diseases could be coexisting in the Donne's period.

As we indicated, the epidemiology the source and the vector, are different in the two diseases although they are associated with common hygienic and sanitary conditions. Typhus manifests itself in a cold season, Donne had the disease in November, the time of more cases due to wear more clothes. Therefore, the source of contagion was in the case of typhus the dresses worn by people with body lice in addition to fleas. Samuel Pepys (1633-1703) in his diaries [25] says that he did not wash more than exceptionally, but in February 1664 his wife did it and discovered the pleasures of the bathroom and did not allow him to enter on the bed until he did the same, which took 3 days to complete. He washed his feet every few weeks or when he was going to enjoy a night of sexual rejoicing, curiously his wife died of exanthematic typhus. Hygiene was poor at that time and caused diseases such as typhus. It is a Bohemian doctor, Tobias Coberus, who makes the first description (1606) in which he relates the abundance of lice with the disease in his treatise Observations castrensium et ungaricarum [26].

Donne only mentions lice in the Sermons [27]:

God punished the Egyptian with little things: with hailstones, and frogs, and grasshoppers; and Pharaoh's conjurers, that counterfeited all Moses' greater works, failed in the least, in the making of lice.

Alfonso López Corella, in his work [18], tells that it is due to the bite of some insects (he talks in general of insects not just fleas) and called the disease "tabardillo", "aphid", "tabardete", "punticular" and "tuberquillo".

\section{TYPHOID CLINIC AND TREATMENTS IN DEVOTIONS}

Donne's symptoms appear as indicated on November 2324, 1623 (Table 1), the disease appears as a sudden fever with frontal headache [28]. A symptom of typhus was a persistent and high annoying tinnitus with vertigo and a feeling of weight or head load.

Luis de Toro [17] tells that it starts with great laxity of the whole body and then there is heaviness and pain between the scapulae. The face becomes very hot, the eyes are injected with blood and tear incessantly. There is a vehement headache; the pulse becomes large, as in pleurisy; they feel a serious weight in the lumbar region; they sleep little and uneasily: most of the time they have sleeplessness and delirium; the urine is very ingrown and murky ... inextinguishable thirst, anxiety, nausea, vomiting, roughness and blackness of the tongue. If the dominant mood was melancholy, the patients had, in addition to what was indicated, sad delusions, the dream was very disturbed, fear, sadness and fainting ... It produces atrocious delusions, in other fatiguing vigils; some leave them deaf; to other dumb, some comatose and stunned or convulsed and shaky.

Although Donne's red urine (Meditation I) may have been a hematuria due to the disease, he may be referring to 


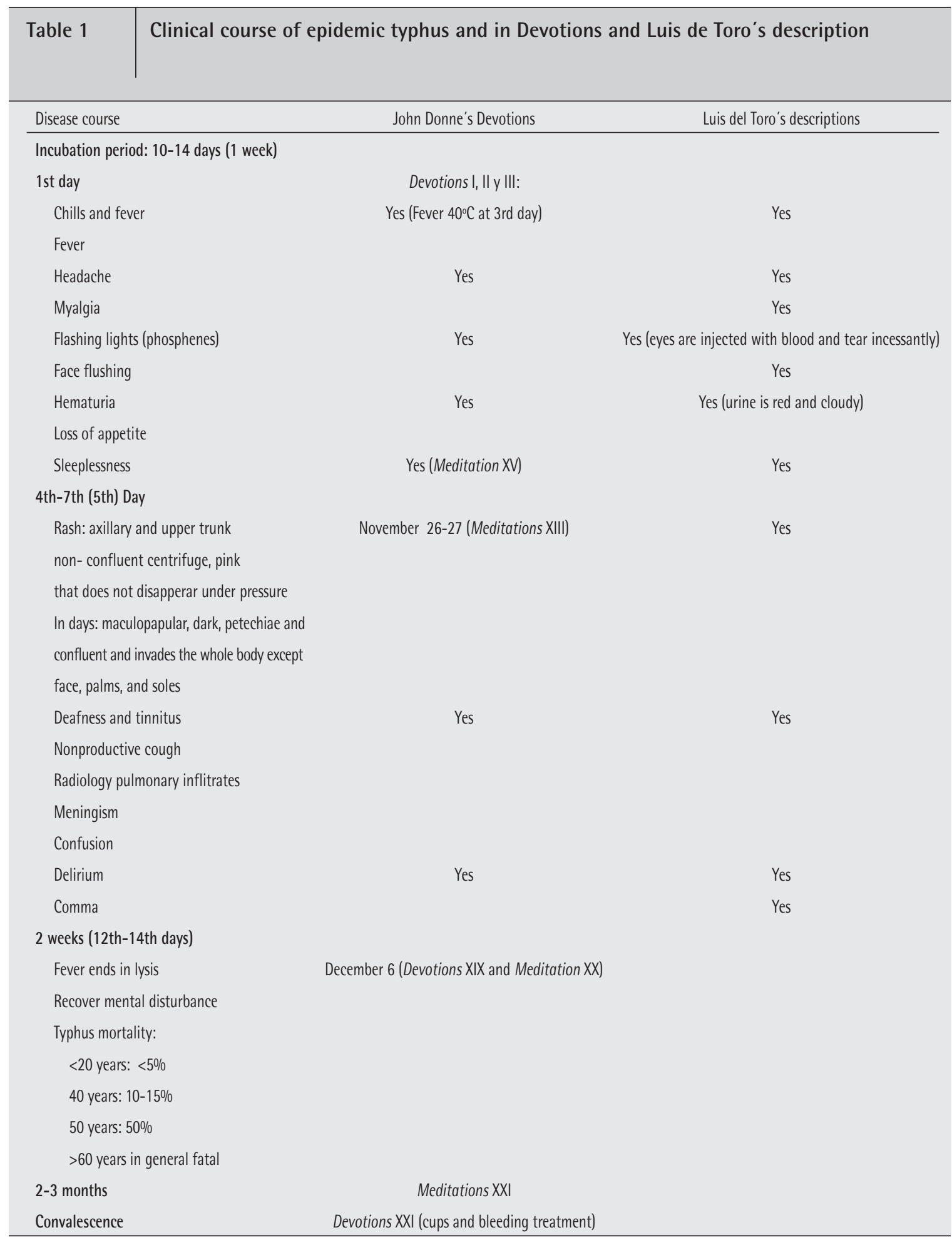

the first of the 10 plagues in Egypt and speak metaphorically. And hydrops of the heavens in Meditation X can refer to the retention of urine in the typhoid or a metaphor. In Meditation III that speaks through stones, it can refer to talking with pustules in the mouth and pharynx that occur as clinical manifestations in typhus or refer to Demosthenes speaking with stones to practice. The suffocation, in Meditation XII, may be the pulmonary phlegm and cough that accompanies typhus. As Frost says [15], symptoms are screened with symbols and rhetoric remedies. 
In delirium, the patient speaks loudly incessantly, singing, making noises night and day. Dr. John Amstrong, in the early nineteenth century, suffered a typhus attack and says that during the illness he wanted to collect all the neurological symptoms that appeared [29]. Also it is known that a rare complication of typhoid fever, caused by Salmonella spp., are psychiatric manifestations.

The treatment followed the principles of Galenic and Paracelsian medicine, was symptomatic and supportive, maintaining nutrition and fluid balance, preventing heart failure, mitigating fever and the consequences of delirium [8]. The treatment would be 5 indications [18]: the regime, the cooking of the moods, the evacuation, the revulsion and the repair of forces. Patients who took more food healed better and convalesced sooner than those undergoing a debilitating diet. Of the purgatives, he prefers drastic ones to the simple and soft ones, for example the cooking of "albérchigo" leaves. Bleeding only in case of need and not always in all cases and should be proportionate to the disease and the forces of the sick.

The strangest treatment was the application of pigeon carcasses on the soles of the feet, this practice is cited by several English writers: John Webster in his work The Duchess of Amalfi (Act III, scene 1, 11.45-50) [30]:

Bosola: I would sooner eat a dead pigeon taken from the soles of the feet of one sick of the plague than kiss one of you fasting.

This work was printed in 1623, the same year of Donne's disease but which was already written in 1614 and in The Diary of Samuel Pepys. Thomas Lodge also cites the pigeon carcasses in his "Plague Treaty" of 1603 and is used by Shakespeare's own son-in-law, doctor John Hall when he had a fever in 1632 [15].

Luis de Toro or Luis Mercado, who used or wrote in his book the most animals and his products in his time, does not mention the use of pigeons in the same manner as in England's doctors [31]. Finally, Corella quotes instead an oil from Florence: "Now there is also a certain secret oil, brought from Florence, with which they say they should anoint the palms and soles of the feet, and also the wrists and the region that is next to the heart, I certainly believe that this is the oil that Mathiolo from Siena describes against poisons, but, in truth, it is too warm, so if it is a burning fever, it should be tempered with some cold medicine. But in the absence of this oil, scorpion oil in which blessed thistle, decree and scorzone would have been useful. Well, yes, to attract the humors from the inside outwards in the burning fever, Aecio praise the oil or water, in which nitro had been poured, it should not be denied that to seek a similar action the predicted oil must be useful. Add the fact that, by a certain antipathy, he opposes poison. " (" Ahora también se tiene por gran secreto cierto óleo, traido desde Florencia, con el que dicen se deben ungir las palmas y las plantas de los pies, y también las muñecas y la región que está junto al corazón. Ciertamente creo que se trata del oleo que contra los venenos describe Mathiolo de Siena; pero, en verdad, éste es demasiado cálido, por lo cual, si se trata de una fiebre ardiente, se debería atemperar con algún medicamento frío. Pero a falta de este aceite, será útil el aceite de escorpiones en el que se hubiese echado cardo bendito, dictamo y escorzonera. Pues si, para atraer los humores desde el interior hacia el exterior en la fiebre ardiente, Aecio alaba el aceite o el agua, en la que se hubiese vertido nitro, no se debe negar que para procurar una acción similar ha de ser útil el oleo predicho. Añade el hecho de que, por cierta antipatía, se opone al veneno.") [18].

\section{FUNDING}

None to declare

\section{CONFLICT OF INTEREST}

The authors declare that they have no conflicts of interest

\section{REFERENCES}

1. Arrizabalaga J. Problematizing retrospective diagnosis in the history of disease. Asclepio 2002; vol. LIV-1: 51-70. DOI: 10.3989/asclepio.2002.v54.i1.135

2. Young RV. "O My America, My New-Found-Land": Pornography and Imperial Politics in Donne's "Elegies". South Central Review. 1987; 4: 35-48. DOI: 10.2307/3189162).

3. Woollam DHM. Donne, disease and doctors. Medical allusions in the works of the seventeenth-century poet and divine. J Anat. 1987; 153: 245-246. PMC:1261799.

4. Charles Creighton, History of Epidemics in Britain. Cambridge: Cambridge University Press, 1891, p. 503.

5. Dickinson A. I am every dead thing: John Donne and death. Discovering Literature: Shakespeare \&t Renaissance. [cited 19th August 2019]. Available in: https://www.bl.uk/shakespeare/articles/ i-am-every-dead-thing-john-donne-and-death?mobile=on.

6. Perrine L. Explicating Donne: "The Apparition" and "The Flea". JSTOR. 1990; 17: 1-20. www.jstor.org/stable/25111839.

7. Donne J. Devociones para circunstancias inminentes y Duelo por la muerte (Trad. Jaime Collyer). Ed. Navona_Ineludibles 2018.

8a. Kate F. John Donne's Devotions; An early record of epidemics typhus. J Hist Med 1976; 31:421-430. DOI: 10.1093/jhmas/xxxi.4.421;

8b. McSherry J. John Donnes's sickness. Can Med Assoc J. 1986; 134:105. PMID: 3510693

9. Bald RC. John Donne: a life. Oxford, 1970

10. John Donne's Devotions. Available in: https://www.ccel.org/ccel/ donne/devotions.html. (cited 12th December 2019).

11. Lander C. A dangerous sickness which turned to a spotted fever. Studies in English Literature, 1500-1900, JSTOR. 1971; 11: 89-108. www.jstor.org/stable/449820. DOI: 10.2307/449820.

12. Honigsbaum M. The patient's view: John Donne and Katharine Anne Porter. The Lancet. 2009; 374: 194-195. DOI: 10.1016/s01406736(09)61319-2 
13. Hawkins A. Two pathographies: a study in illness and literature. J Med Philos. 1984; 9:231-52. DOI: 10.1093/jmp/9.3.231.

14. Allen DC. John Donne's knowledge of Renaissance Medicine. J Engl. \& German Philop. 1943; 42: 322-342. https://www.jstor.org/ stable/27705006.

15. Frost K. Prescription and devotion: the Reverend Doctor Donne and the learned Doctor Mayerne-two seventeenth-century records of epidemic typhus fever. Medical History, 1978, 22: 408-416. https:// doi.org/10.1017/S0025727300033421.

16. Azizi MH, Bahadori M, Azizi F. An Overview of Epidemic Typhus in the World and Iran during the 19th and 20th Centuries. Arch Iran Med. 2016; 19:747-750. D0I: 0161910/AIM.0015

17. De Toro L. De la fiebre epidémica y nueva, en latín punticular, vulgarmente tabardillo y pintas. Instituto de España, Real Academia de Medicina, Biblioteca clásica de la Medicina Española (tomo XIII), Madrid 1961.

18. Alonso López de Corella: De Morbo Pustulato, sive Lenticulari, quem Nostrates Tabardillo Apellant (Introducción, traducción y notas José Ramón Gurpegui Resano). Available in: https://www. ehu.eus , documents , De_morbo_pustulato. (Cited: 12th December 2019).

19. Corominas J (ed.). Breve diccionario etimológico de la lengua castellana (3era edición). Ed. Gredos, Madrid 1976, p 551.

20. De Covarrubias Horozco S. Tesoro de la lengua castellana o española. Universidad de Navarra, Ed. Iberoamericana, Madrid 2006.

21. Marañón G. Antonio Pérez. Ed. Espasa Calpe, Madrid, 1998.

22. Angelakis $E$, Bechah $Y$, Raoult $D$. The history of epidemic typhus. Microbiol Spectr. 2016; 4 (4). DOI: 10.1128/microbiolspec.PoH0010-2015.

23. Dean KR, Krauer F, Walløe L, Lingjærde OC, Bramanti B, Stenseth $N C$ et al. Human ectoparasites and the spread of plague in Europe during the Second Pandemic. Proc Natl Acad Sci U S A. 2018; 115: 1304-1309. doi: 10.1073/pnas.1715640115).

24. Vincent B. Las epidemias en Andalucía durante el siglo XVl|, V Congreso Nacional de la Sociedad Española de Historia de la Medicina, Madrid (1977). Asclepio 1979; 29: 351-8. En: http://www.sehm.es/pages/reuniones-ycongresos/vcongresonacionaldehistoriadelamedicinavoli/\%21. (Cited: $12^{\text {th }}$ December 2019.

25. Stone L. The family, sex and marriage in England 1500-1800. Ed. Penguin 1979.

26. García del Real E. Notas a propósito de la historia del tifus exantemático. El Siglo Med 1933; 91: 431-9, 460-5, 492-5. Available in: https://www.ehu.eus , documents , De_morbo_ pustulato. (Cited: 12th December 2019).

27. The Sermons of John Donne Volume II. Available in: https:// archive.org/stream/sermonsofjohndon009115mbp/ sermonsofjohndon009115mbp_djvu.txt. (Cited: 12th December2019).

28. Bateman T. A succinct account of the typhus or contagious fever of this country. London: Longman Hurst, 1820, p. 16.

29. Amstrong J. Practical Illustrations of typhus and other fevers. Boston: Timothy Bedlington, 1829, p. 89-92.
30. Webster J. Three plays: The white devil, The Duchess of Malfi, The devil's law-case. Penguin Books, 1976.

31. Rojo Vera A. Ludovicus Mercatus. Luis de Mercado, protomédico general de las Españas (1532-1611). Universidad y Ayuntamiento de Valladolid, 2011. 